\title{
Lansia dan Pertanian Perkotaan
}

\author{
Rini Fitri ${ }^{1}$ dan Suryani ${ }^{2}$ \\ ${ }^{1}$ Study Program of Agrotechnology, Faculty of Agriculture, Almuslim University, Bireuen, Aceh \\ ${ }^{2}$ Study Program of Agrotechnology, Faculty of Agriculture, University of Respati Indonesia, Jakarta \\ Email:edmaryani@yahoo.co.id
}

\begin{abstract}
ABSTRAK
Lansia kerap sekali dianggap sebagai beban keluarga dan dinilai tidak produktif, stigma negatif tersebut harus diubah oleh lansia sendiri. Masalah yang sering dijumpai pada lansia adalah kurangnya nafsu makan, proses pencernaan yang tidak sempurna, sulit buang air besar, dan pemanfaatan makanan sebagai sumber energi. Lansia harus bangkit dan didukung oleh masyarakat serta pemerintah sehingga lansia menjadi produktif, bermanfaat, sehat, dan bahagia. Suatu proses yang tidak dapat dihindari yang berlangsung secara terus-menerus dan saling berkaitan yang selanjutnya menyebabkan perubahan anatomis, fisiologis, dan biokemis pada jaringan tubuh dan akhirnya mempengaruhi fungsi dan kemampuan badan secara keseluruhan. Pertanian perkotaan merupakan salah satu solusi bagi lansia untuk beraktivitas di pekarangan rumah agar terjadi aktivitas fisik dan mengurangi depresi. Aktivitas pertanian di perkotaan pada lahan terbatas di DKI Jakarta yaitu budidaya sayuran, palawija dan hortikultura yang pelakunya adalah ibu-ibu rumah tangga dan lansia. Parktik pertanian mengajak lansia untuk mengekspresikan diri sendiri bahwa mereka memiliki kemampuan dan kapabilitas dalam melaksanakan sesuatu yang mendukung identitas dan otonomi mereka. Tulisan ini bertujuan menguraikan aktivitas pertanian di perkotaan pada lahan pekarangan terbatas bagi lansia.
\end{abstract}

Kata Kunci: pertanian perkotaan, lanjut usia, kesehatan

\begin{abstract}
The elderly are often considered as a burden on the family and considered unproductive, the negative stigma must be changed by the elderly themselves. Problems that are often encountered in the elderly are lack of appetite, imperfect digestion, difficulty defecating, and the use of food as an energy source. The elderly must rise up and be supported by the community and the government so that the elderly become productive, useful, healthy, and happy. An unavoidable process that takes place continuously and interrelated which in turn causes anatomical, physiological, and biochemical changes in body tissues and ultimately affects the function and ability of the body as a whole. Urban agriculture is one solution for the elderly to be active in the yard so that physical activity occurs and reduces depression. Agricultural activities in urban areas on limited land in DKI Jakarta are the cultivation of vegetables, secondary crops and horticulture, the perpetrators of which are housewives and the elderly. Agricultural practice invites the elderly to express themselves that they have the ability and capability to do something that supports their identity and autonomy. This paper aims to describe agricultural activities in urban areas on limited land for the elderly.
\end{abstract}

Keywords: urban agriculture, elderly, health

\section{PENDAHULUAN}

Laju penuaan populasi di negara

berkembang saat ini secara substansial lebih

cepat terjadi dibandingkan di negara maju. http://ejournal.urindo.ac.id/index.php/pertanian
Akibatnya, kini negara-negara berkembang harus beradaptasi lebih cepat dengan populasi yang menua. Data statistik tahun 2018 terdapat 9,27 persen dari total 
populasi penduduk di Indonesia atau 24,5 juta di antaranya adalah lansia baik itu lansia muda, madya, maupun tua. Sebagian besar lansia Indonesia, sebanyak 13,97 persen bermukim di Daerah Istimewa Yogyakarta (DIY). Empat provinsi dengan jumlah lansia tertinggi adalah Jawa Tengah (12,92 persen), Jawa Timur (12,54 persen), Bali $(10,96$ persen), dan Sulawesi Utara (10,73 persen). Jumlah penduduk lansia berdasarkan data proyeksi penduduk, diperkirakan tahun 2017 terdapat 23,66 juta jiwa penduduk lansia di Indonesia (9,03\%) Diprediksi jumlah penduduk lansia tahun 2020 (27,08 juta), tahun 2025 (33,69 juta), tahun 2030 (40,95 juta), dan tahun 2035 (48,19 juta) [1].

Lansia kerap sekali dianggap sebagai beban keluarga dan dinilai tidak produktif, stigma negatif tersebut harus diubah oleh lansia sendiri. Lansia harus bangkit dan didukung oleh masyarakat serta pemerintah sehingga lansia menjadi produktif, bermanfaat, sehat, dan bahagia. Pentingnya para kakek dan nenek mengembangkan potensi diri, mereka diajar agar memiliki kekuatan spiritual, pengendalian diri, juga aktivitas fisik dan keterampilan yang berguna bagi diri sendiri dan masyarakat. Jenis aktivitas fisik yang berpengaruh terhadap fungsi kognitif adalah olahraga aktif, berenang, jalan kaki dan latihan fisik. Lansia yang tidak pernah melakukan kegiatan-kegiatan fisik akan beresiko 1,4 sampai 1,6 lebih besar untuk mempunyai fungsi kognitif buruk dibandingkan dengan lansia yang melakukan kegiatan-kegiatan fisik [2].

Pertanian perkotaan merupakan salah satu solusi bagi lansia untuk beraktivitas di pekarangan rumah agar terjadi aktivitas fisik dan mengurangi depresi. Pertanian perkotaan merupakan kegiatan pertumbuhan, pengolahan, dan distribusi pangan serta produk lainnya melalui budidaya tanaman dan peternakan yang intensif di perkotaan dan daerah sekitarnya, dan menggunakan (kembali) sumber daya alam dan limbah perkotaan, untuk memperoleh keragaman hasil panen dan hewan ternak [3]. Pertanian perkotaan di Indonesia sudah mulai di kembangkan terutama masyarakat-masyarakat kota besar seperti DKI Jakarta, Surabaya dan Bandung. Konsep pertanian perkotaan untuk wilayah Asia diperkirakan berasal dari Shanghai, Tiongkok. Sebagai salah satu kota besar yang terus berkembang, Shanghai tetap menjaga pertanian perkotaan sebagai bagian dari sistem ekonomi untuk mendukung perkembangan kota. Meskipun demikian, wilayah pengembangan pertanian bergeser ke daerah pinggiran kota karena masifnya pembangunan perumahan dan gedung perkantoran di pusat kota [4].

Aktivitas pertanian di perkotaan pada lahan terbatas di DKI Jakarta yaitu budidaya sayuran, palawija dan hortikultura yang pelakunya adalah ibu-ibu rumah tangga dan 
lansia. Salah satu terapi yang digunakan untuk menurunkan depresi pada lansia yaitu terapi hortikultura. Hortikultura merupakan bagian dari aktivitas pertanian perkotaan yang umum digunakan oleh masyarakat perkotaan yang memiliki lahan sempit dan biasanya dilakukan oleh ibu rumah tangga dan lansia [5].

Terapi hortikultura lansia memiliki rentang tingkat depresi mulai dari tidak ada gejala depresi sampai depresi ringan, terapi hortikultura untuk menurunkan tingkat depresi lansia sangatlah efektif. Kegiatan berkebun atau hortikultura memiliki pengaruh positif untuk semua kalangan usia dimana dapat mengurangi gejala depresi seperti insomnia dan nyeri psikosomatik [6]. Kegiatan berkebun pada lahan pekaranan sempit di perkotaan ini merupakan aktivitas yang sangat sering dilakukan oleh orang dewasa dan dapat diterima dengan baik di kalangan lansia. Tulisan ini bertujuan menguraikan aktivitas pertanian di perkotaan pada lahan pekarangan terbatas bagi lansia.

\section{PERUBAHAN FISIK LANSIA}

Suatu proses yang tidak dapat dihindari yang berlangsung secara terusmenerus dan saling berkaitan yang selanjutnya menyebabkan perubahan anatomis, fisiologis, dan biokemis pada jaringan tubuh dan akhirnya mempengaruhi fungsi dan kemampuan badan secara keseluruhan. Perubahan - perubahan yang terjadi pada lansia dapat dikelompokkan menjadi 4 (empat), yaitu perubahan fisiologis, perubahan psikologis, perubahan sosial dan perubahan ekonomi. Usia Permulaan tua menurut UndangUndang Nomor 13 Tahun 1998 tentang lanjut usia menyebutkan bahwa umur 60 tahun adalah usia tua. Proses menua dan lanjut usia merupakan proses alami yang dialami oleh setiap orang [7].

Perkembangan hubungan pada Lansia adalah terjadinya perubahan hubungan yang tadinya antara anak dengan orang tua, tetapi pada masa lansia terjadi perkembangan hubungan antara Nenek atau Kakek dengan Cucunya. Keberadaan cucu sangat membantu respon psikososial lansia ke arah respon adaptif, oleh karena itu sebagai anggota keluarga harus ikut menjembatani tahapan hubungan antara lansia dengan cucunya agar tercipta suasana hubungan yang harmonis. Populasi lansia di dunia dari tahun ke tahun semakin meningkat bahkan pertambahan lansia menjadi semakin mendominasi apabila dibandingkan dengan pertambahan populasi penduduk pada kelompok usia lainnya [8]. Tahun 2050, satu dari lima orang di dunia akan berusia 60 tahun dan lebih tua, pada tahun 2015 dan 2030 jumlah orang lanjut usia di seluruh dunia meningkat menjadi 56 persen, dari 901 juta menjadi lebih dari 1,4 miliar. Tahun 2030, jumlah orang berusia 60 
ke atas akan melebihi usia muda yang berusia 15 sampai 24 tahun [9]. Perubahanperubahan yang biasanya terjadi pada lansia diantaranya adalah perubahan fisik, komposisi tubuh, otot, tulang, sendi, sistem kardiovaskular, respirasi dan kognisi.

Disitribusi lemak berubah dengan bertambahnya usia. Laki-laki dengan bertambahnya usia akan mengakumulasi lemak terutama disekitar batang tubuh dan di sekitar organ-organ dalam sedangkan wanita terutama disekitar organ-organ dalam. Pada atlet senior mereka memilki kadar lemak lebih rendah dibandingkan non atlet, namun apabila dibandingkan dengan atlet muda mempunyai kadar lemak 5-10\% lebih tinggi [10]. Perubahan usia datang tanpa disadari, lansia merupakan suatu kejadian yang pasti dialami secara fisiologis oleh semua orang yang dikaruniai usia panjang [11]. Lanjut usia akan mengalami proses penuaan, yang merupakan proses terus-menerus secara alamiah. Penurunan kondisi fisik/fisiologis yang di alami lansia ditandai dengan kulit yang mulai keriput, penglihatan dan pendengaran berkurang, gigi ompong, mudah lelah, gerakan lamban [12]. Oleh sebab itu, lansia merupakan sosok yang sarat dengan berbagai penurunan, baik fisik, psikologis maupun sosial. Dalam menjalani kehidupan tentunya memerlukan pendamping atau dukungan dari orang lain seperti pasangan hidup (istri atau suami), keluarga dan teman sosialnya dalam menjalani kehidupan sehari-hari.

\section{AKTIVITAS FISIK LANSIA}

Masalah yang sering dijumpai pada lansia adalah kurangnya nafsu makan, proses pencernaan yang tidak sempurna, sulit buang air besar, dan pemanfaatan makanan sebagai sumber energi. Dengan adanya masalah ini, maka dirancang suatu latihan fisik yang bertujuan untuk menambah nafsu makan (input), memperlancar proses pencernaan dan buang air besar (proses), dan mengefisienkan pemanfaatan energi di tubuh (out put). Aktivitas fisik merupakan suatu kegiatan/aktivitas yang menyebabkan peningkatan penggunaan energi atau kalori oleh tubuh [13]. Aktivitas fisik maupun aktivitas sehari-hari (Activity Daily Living) sangat penting dalam kehidupan lansia agar lansia menjadi mandiri. Aktivitas fisik dalam kehidupan sehari-hari dapat dikategorikan ke dalam pekerjaan, olahraga, kegiatan dalam rumah tangga ataupun kegiatan lainnya [14]. Aktivitas fisik dapat dilakukan sesuai dengan kemampuan dan keadaan fisik lansia. Dalam hal kesehatan, sebaiknya lansia rutin mengikuti Pos Pembinaan Terpadu untuk mengetahui tekanan darah dan Indeks Massa Tubuh setiap bulan agar lasia dapat mengontrol hal-hal apa yang sebaiknya dilakukan dan tidak dilakukan 
untuk menjaga kestabilan tekanan darah dan Indeks Massa Tubuh.

Faktor usia sangat berpegaruh terhadap kemampuan beraktivitas fisik, pemilihan jenis olahraga dan aktivitas sehari-hari juga sangat bergantung dari kemampuan usila tersebut. Semakin meningkat umur, kemampuan beraktivitas fisik juga akan berkurang antara $30-50 \%$ [15]. Pemilihan aktivitas fisik bagi lansia adalah sesuai dengan kondisi kesehatannya, sebaiknya diskusikan dulu dengan dokter yang merawatnya. Jika lansia tersebut tidak dianjurkan untuk berolahraga berat, maka bisa memilih kebutuhan fisik dengan rutin melakukan aktivitas fisik sedang setiap hari selama paling sebentar setengah jam sehari. Agar keseimbangan tetap terlatih, baik senam lansia, tai chi, atau yoga. Dengan melakukan program aktivitas fisik jangka pendek seperti latihan fisik dapat membawa perbaikan yang berarti dalam kinerja fungsi kognitif lansia [16].

Sementara untuk melatih otot sebenarnya bisa dilakukan dengan aktivitas apa pun yang menggunakan otot tertentu, misalnya otot tangan dilatih dengan cara berkebun setiap hari di pekarangan rumah. Intensitas aktivitas fisik merupakan seberapa keras suatu aktivitas dilakukan, biasanya diklasifikasikan menjadi intensitas ringan, sedang, dan berat [17]. Adapun manfaat aktivitas fisik akan menguatkan otot jantung dan memperbesar bilik jantung, kedua hal ini akan meningkatkan efisiensi kerja jantung. Manfaat fisik ini, berbagai penyakit degeneratif (mis: jantung, hipertensi, diabetes mellitus, rematik) akan tercegah atau sedikit teratasi. Berat badan tubuh terpelihara dan kebugaran akan bertambah sehingga produktivitas akan meningkat dan dapat menikmati masa tua dengan bahagia.

\section{PRAKTIK URBAN FARMING PADA LANSIA}

$$
\text { Praktik pertanian mampu }
$$

meningkatkan wellbeing lansia, peningkatan kesehatan menurut penilaian individu sendiri, dan meningkatkan interaksi sosial dengan lingkungan sekitar. Parktik pertanian mengajak lansia untuk mengekspresikan diri sendiri bahwa mereka memiliki kemampuan dan kapabilitas dalam melaksanakan sesuatu yang mendukung identitas dan otonomi mereka. Berdasarkan hasil penelitian ditemukan bahwa self-esteem dan selfefficacy meningkat ketika orang berpartisipasi dalam program pertanian [18]. Disamping itu program-program pelayanan sosial akan membantu lansia dalam mengisi waktu luang seperti bimbingan mental dan spiritual, rekreasi, penyaluran hobi dan bakat, senam dan bercocok tanam. Tridarma pengabdian kepada masyarakat yaitu kegiatan praktik pertanian perkotaan bagi lansia yang dilakukan oleh dosen Universitas Respati Indonesia disajikan pada Gambar 1. 

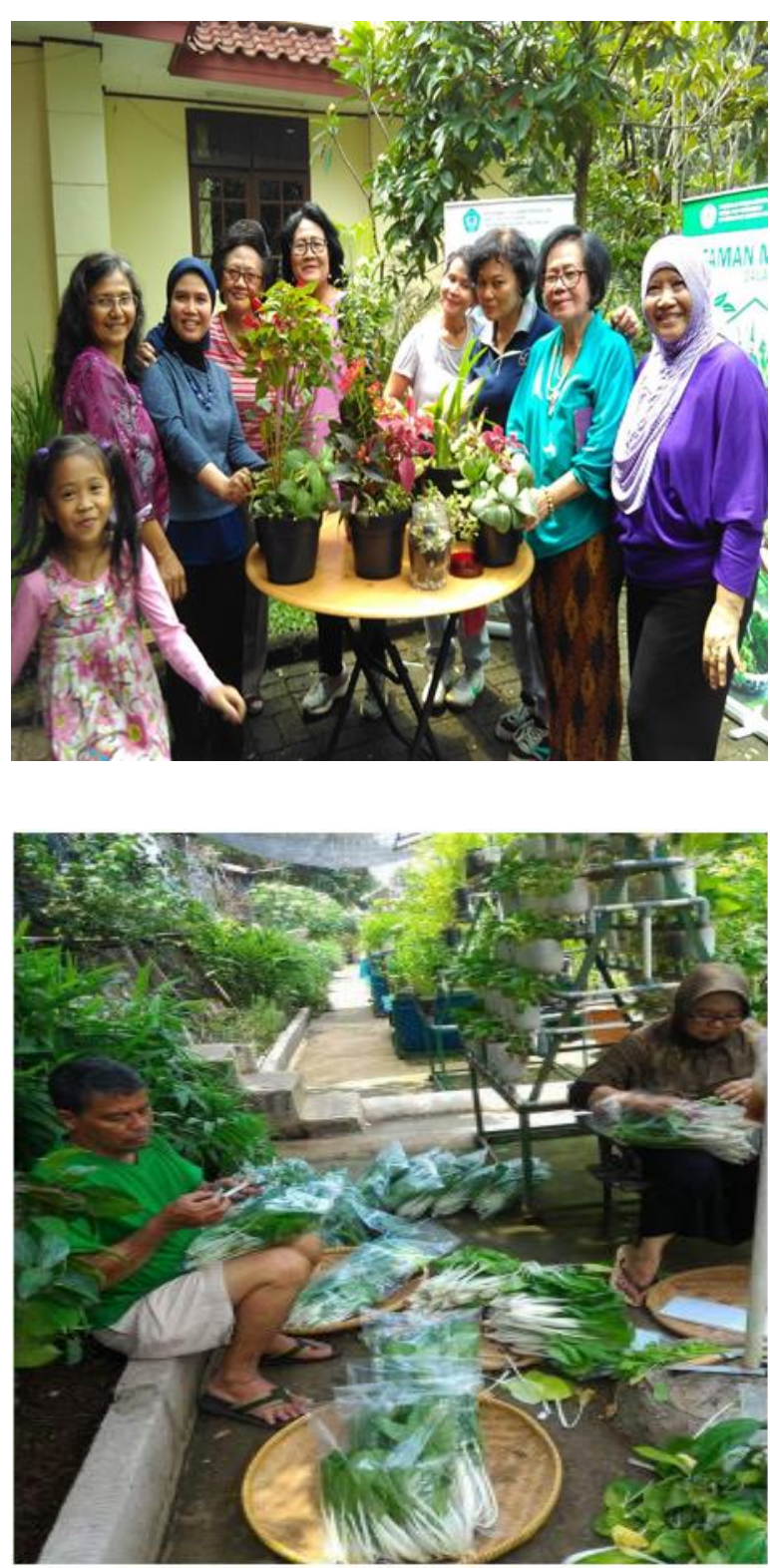

Gambar 1. Praktik Urban farming yang dilakukan lansia DKI Jakarta (Sumber:

Fakultas Pertanian Universitas Respati Indonesia)

\section{KESIMPULAN}

Lansia harus bangkit dan didukung oleh masyarakat serta pemerintah sehingga lansia menjadi produktif, bermanfaat, sehat, dan bahagia. Pertanian perkotaan merupakan salah satu solusi bagi lansia untuk beraktivitas di pekarangan rumah agar terjadi aktivitas fisik dan mengurangi depresi. Aktivitas pertanian di perkotaan pada lahan terbatas di DKI Jakarta yaitu budidaya sayuran, palawija dan hortikultura yang pelakunya adalah ibu-ibu rumah tangga dan lansia. Praktik pertanian mengajak lansia untuk mengekspresikan diri sendiri bahwa mereka memiliki kemampuan dan kapabilitas dalam melaksanakan sesuatu yang mendukung identitas dan otonomi mereka.

\section{DAFTAR PUSTAKA}

Kementrian Kesehatan RI. 2017. Analisis Lansia di Indonesia. http://www.depkes.go.id/resources/d ownload/pusdatin/lainlain/Analisis\%2 OLansia\%20ln donesia\%202017.pdf. Diakses tanggal 19 September 2019.

Wreksoatmodjo, R.B. 2016. Pengaruh Aktivitas Fisik terhadap Fungsi Kognitif Lanjut Usia di Jakarta. CDK 236.1(43): 8-10.

Food and Agriculture Organization (FAO). 2008. Urban Agriculture For Sustainable Poverty Alleviation and Food Security. 84p.

Girardet, H. 2005. Urban Agriculture And Sustainable Urban Development. In CPULS: Continuous Productive Urban Landscapes-Designing Urban Agriculture for Sustainable Cities; 
Viljoen, A., Ed.; Elsevier: Amsterdam, The Netherlands; pp. 32-39.

Detweiler, M.B. dan Sharma, T. 2012. What is The Evidence to Support The Use of Theraupeutic Gardens for Elderly?. Korean Beuropsychiatric Association. (9)2: 100.

Ghanbari, Sahar. 2015. Study of The Effect Of Using Purposeful Activity Gardening on Depression on Female Resident in Golesten Dormitory of Ahvaz Jundishapur. University of Medical Sciences. JRSR. (2)1: 98-99.

Kementerian Kesehatan RI (2014). Pusat Data dan Informasi. Jakarta Selatan. Mengenai Usia Lanjut dan Perawatannya. Salemba Medika. hal 32.

Stuart, GW. Laraia, MT. 2001. Principtes and Practice of Psychiatric Nursing.5h ed. philadelphia : Mosby Compay.

Unidop. 2017. International Day Of Older Person 2017. https://www.un.org/development /desa/ageing/international-dayofolderpersonshomepage/unidop2012.html. Diakses tanggal 19 September 2019. Wojtek Chodzo. 2000. The Active Aging Blueprint: A National Initiative for The Promotion of Successful Aging. Departement of Kinesiology University of Illinois. USA.
Rafknowledge. 2004. Insomnia dan Gangguan Tidur Lainnya. Jakarta. PT. Elex Jakarta.

Bahewa E, Rumende R, Rondouwu P. 2014. Pengaruh Aktivitas Fisik: Senam Lansia terhadap Stabilisasi Tekanan Darah pada Lansia Di Jemaat Torsina Desa Bitunuris Kecamatan Salibabu Kabupaten Kepulauan Talaud. Buletin Sariputra. 4(3): 218-223.

Caspersen C, Powell K, Christenson G. 1985. Physical Activity, Exercise, and Physical Fitness: Definitions and Distinctions for Health-Related Research. Public Health Reports. 100(2): 126-131.

Martini RD, Afriwardi, Muzamil MS. 2014. Hubungan Antara Tingkat Aktivitas Fisik dengan Fungsi Kognitif pada Usila di Kelurahan Jati Kecamatan Padang Timur. Jurnal Kesehatan Andalas. 3(2): 203-205.

Jones, C.J, Rose, D.J. 2005. Physical Activity Instruction of Older Adults. United States of America: Human Kinetics.

Landefeld, S.C. 2004. Current Geriatric Diagnosis dan treatment. Singapore: The Mc Graw-Hills Company.

Gibson, R. B. \& Hughes, M. P. 2000. Treatment of the Sexually Violent Predator: A horticultural Approach. Journal of therapeutic horticulture, 11. 